\title{
Detection of a Geminivirus Infecting Sweet Potato in the United States
}

\author{
P. Lotrakul, R. A. Valverde, C. A. Clark, J. Sim, and R. De La Torre, Department of Plant Pathology and Crop \\ Physiology, Louisiana Agricultural Experiment Station, Louisiana State University Agricultural Center, Baton \\ Rouge 70803
}

\begin{abstract}
Lotrakul, P., Valverde, R. A., Clark, C. A., Sim, J., and De La Torre, R. 1998. Detection of a geminivirus infecting sweet potato in the United States. Plant Dis. 82:1253-1257.

In 1994, a sweet potato sample showing leaf curl symptoms was collected from the field in Louisiana. When graft-inoculated, Ipomoea nil cv. Scarlett O'Hara reacted with severe leaf distortion and chlorosis symptoms. I. aquatica reacted with a bright yellow mottle. The virus isolated was designated the United States isolate of sweet potato leaf curl virus (SPLCV-US). It was transmitted to I. nil by the sweet potato whitefly, Bemisia tabaci biotype B. DNA probes prepared with component $\mathrm{A}$ of pepper Huasteco geminivirus, with an isolate of bean golden mosaic geminivirus from Guatemala, with an isolate of tomato mottle geminivirus from Florida, and with an isolate of tomato yellow leaf curl geminivirus from the Dominican Republic (TYLCV-DR) hybridized with a 2.6-kb DNA band present in DNA extracts from plants infected with SPLCV-US. Probes prepared with the B component of these geminiviruses did not hybridize with these DNA extracts. We were unable to amplify SPLCV-US DNA products by polymerase chain reaction (PCR) in quantities that could be visualized by ethidium bromide staining. However, Southern blots from amplifications with primers AV494/AC1048 revealed PCR products of approximately $600 \mathrm{bp}$ and $550 \mathrm{bp}$ when hybridized with the TYLCV-DR probe. These results were consistently obtained from infected I. cordatotriloba and less consistently from I. aquatica or I. setosa. Fibrillar inclusions were occasionally seen, and granular aggregates of viruslike particles were observed in the nucleus of infected I. cordatotriloba. These results suggest that the virus isolated from sweet potato with leaf curl symptoms belongs to the geminivirus group.
\end{abstract}

Sweet potato (Ipomoea batatas (L.) Lam.) ranks seventh in worldwide food production and is an economically important crop in Louisiana. Preliminary data suggest that viruses may significantly affect yield and quality of sweet potatoes and contribute to cultivar decline (C. A. Clark, unpublished data). Although sweet potato has been widely recognized to be infected by viruses, only one well-characterized virus, sweet potato feathery mottle virus (SPFMV), has been reported to occur in sweet potato fields in the United States (2). Recently, a closterovirus was reported infecting in vitro plants of the cultivar White Bunch from the USDA Plant Genetics Resources Unit, Griffin, GA (15). However, there have been many other reports of viruslike symptoms that lacked characterization of the causal virus(es) $(5,7,8)$. Many more viruses have been reported to infect sweet potato in different

Corresponding author: R. A. Valverde

E-mail: rvalver@1suvm.sncc.lsu.edu

Approved for publication by the director, Louisiana Agricultural Experiment Station, manuscript 98-38-0128.

Accepted for publication 4 August 1998.

Publication no. D-1998-0915-01R

(C) 1998 The American Phytopathological Society parts of the world $(2,11-13,17)$. Sweet potato leaf curl virus (SPLCV) $(1,6,9,14)$ and Ipomoea crinkle leaf curl virus (ICLCV) (3), each inducing leaf curl symptoms, have been reported in Taiwan and Japan, and in Israel, respectively. Although complete characterization has not been reported, these reports indicate that the causal agents are whitefly-transmitted geminiviruses.

In 1994, sweet potato samples were collected from various growers and experimental plots in Louisiana and grafted onto I. setosa. Most samples were infected with SPFMV, but many induced more severe symptoms in I. setosa than SPFMV alone. One sweet potato sample from the breeding line W-285 from the USDA-ARS Vegetable Laboratory, Charleston, SC, (planted for variety trials) showed leaf curl symptoms and was designated W-285. When graft-inoculated on I. setosa and $I$. nil cv. Scarlett O'Hara, it induced leaf distortion and chlorosis symptoms. When graft-inoculated, I. aquatica reacted with a bright yellow mottle. SPFMV was present in the original source but had been eliminated by passage through I. aquatica. Because these symptoms were not typical of those induced by other sweet potato viruses, we investigated the identity of the virus(es). Here, we present evidence that suggests that the virus isolated from W-285 with leaf curl and designated the United States isolate of sweet potato leaf curl vi- rus (SPLCV-US) belongs to the geminivirus group.

\section{MATERIALS AND METHODS}

Virus isolates. Shoots from a field-collected sweet potato breeding line W-285 plant showing leaf curl symptoms were grafted onto I. setosa and I. aquatica. SPFMV was then detected by serologically specific electron microscopy in I. setosa but not in I. aquatica, and thus I. aquaticainfected plants were used for subsequent isolations. During whitefly transmission experiments, a single whitefly transmission isolate of SPLCV-US was obtained and used in most experiments. Other viral isolates used for comparison were singleaphid-probe isolates of SPFMV from Louisiana and a whitefly-transmitted isolate of a sweet potato closterovirus infecting the cultivar White Bunch from the USDA Plant Genetics Resources Conservation Unit, Griffin, GA.

Host reactions. Graft-inoculations were conducted using scions from SPLCV-US infected I. aquatica. Graft-inoculated plant species included I. batatas cvs. TIB-8, Tanzania (PI-595887), No. 29 (PI-595889), $\mathrm{W}-285$, and Beauregard, I. aquatica, I. alba, I. cordatotriloba (syn. I. trichocarpa), I. fistulosa, I. lacunosa, I. lobata, I. pupurea, I. saintronanensis, I. tiliaceae, and I. trifida. At least four plants per species were grafted. Symptoms were recorded 2 to 4 weeks after grafting. Graftinoculations to I. aquatica, I. nil, I. setosa, and I. batatas were also conducted using the single-whitefly-transmission isolate of SPLCV-US. I. setosa and I. nil were also graft-inoculated with mixed infections of SPFMV and SPLCV-US. Mechanical inoculations using phosphate buffer, $\mathrm{pH}$ 7.2, were also conducted on the following plant species: Chenopodium quinoa, I. aquatica, I. nil, I. setosa, Nicotiana benthamiana, and $N$. glauca.

Whitefly transmissions. The sweet potato whitefly, Bemisia tabaci biotype B, was used in transmission experiments. Colonies were established on cotton and kept in Plexiglas cages in the laboratory. Single whiteflies and groups of 5, 10, 20, 30 , and 40 were used. Acquisition and transmission feedings were for 2 days. In all cases, 5- to 7-day-old I. nil was used as the transmission host, and I. setosa, I. aquatica, or I. nil infected with SPLCV-US was used as acquisition host. Symptoms were recorded 2 to 3 weeks after transmission feedings. Similar experiments were 
conducted using the banded winged whitefly, Trialurodes abutilonea, except that only groups of 20 were used. Other transmission hosts tested using groups of 40 whiteflies (B. tabaci biotype B) included N. glauca, Capsicum annuum cv. Yolo Wonder, Datura stramonium, Lycopersicon esculentum cv. Rutgers, and $N$. clevelandii. clones of the following geminiviruses were used as probes in molecular hybridization studies: an isolate of tomato yellow leaf curl geminivirus from the Dominican Republic (TYLCV-DR), an isolate of bean golden mosaic geminivirus from Guatemala (BGMV-GA), an isolate of tomato mottle geminivirus from Florida (TMoVFL) (provided by R. Gilbertson, University of California, Davis), and pepper Huasteco geminivirus (PHV) (provided by R. Rivera-Bustamante, CINVESTAV, Mexico). Total DNA was extracted from $1.0 \mathrm{~g}$ of foliar tissues and young shoots of $I$. aquatica, I. nil, I. setosa, I. cordatotriloba, and I. batatas infected with SPLCV-US or noninfected. The method of Dellaporta et al. (4) and, in some experiments, DNeasy (Qiagen, Santa Clarita, CA) were used. and $C$. annuum infected with a Florida isolate of BGMV (BGMV-FL) and PHV, respectively, were used as positive con-
Molecular hybridization. Full-length DNA extracted from Phaseolus vulgaris

trols. DNA was separated in $1.2 \%$ agarose gels in TBE buffer and transferred to nitrocellulose membranes after $\mathrm{NaOH}$ denaturation $(0.5 \mathrm{M} \mathrm{NaOH}$ and $1.5 \mathrm{M} \mathrm{NaCl}$ for $30 \mathrm{~min}$, neutralized in $1.5 \mathrm{M} \mathrm{NaCl}$ and 0.5 M Tris- $\mathrm{HCl}, \mathrm{pH}$ 7.5) (10). Membranes were air-dried and baked at $80^{\circ} \mathrm{C}$ for $2 \mathrm{~h}$. Molecular hybridizations were conducted using Amersham's ECL kit (Arlington Heights, IL) following described procedures (18). Probes were prepared by boiling 0.1 to $0.5 \mathrm{~g}$ of gel-purified DNA (geminivirus components $\mathrm{A}$ and $\mathrm{B}$ separately) in $\mathrm{ddH}_{2} \mathrm{O}$ for 10 min followed by rapid cooling on ice. ssDNA was direct labeled with horseradish peroxidase using glutaraldehyde. The average probe concentration used was $10 \mathrm{ng}$ of probe per ml. Hybridization was conducted overnight at $42^{\circ} \mathrm{C}$ in Amersham's gold hybridization buffer containing $0.5 \mathrm{M} \mathrm{NaCl}$ (high stringency), 5\% Amersham's blocking agent, and Amersham rate enhancer. All membranes were washed under high stringency conditions (two 20-min washes at $42^{\circ} \mathrm{C}$ using $0.1 \times \mathrm{SSC}[0.15 \mathrm{M} \mathrm{NaCl}$ plus 0.015 $\mathrm{M}$ sodium citrate], $6.0 \mathrm{M}$ urea, $0.4 \%$ sodium dodecyl sulfate [SDS]; and two 5min washes at room temperature using $2 \times$ SSC). After washing membranes, chemiluminescent detection reagents were used, and membranes were exposed to X-ray film.

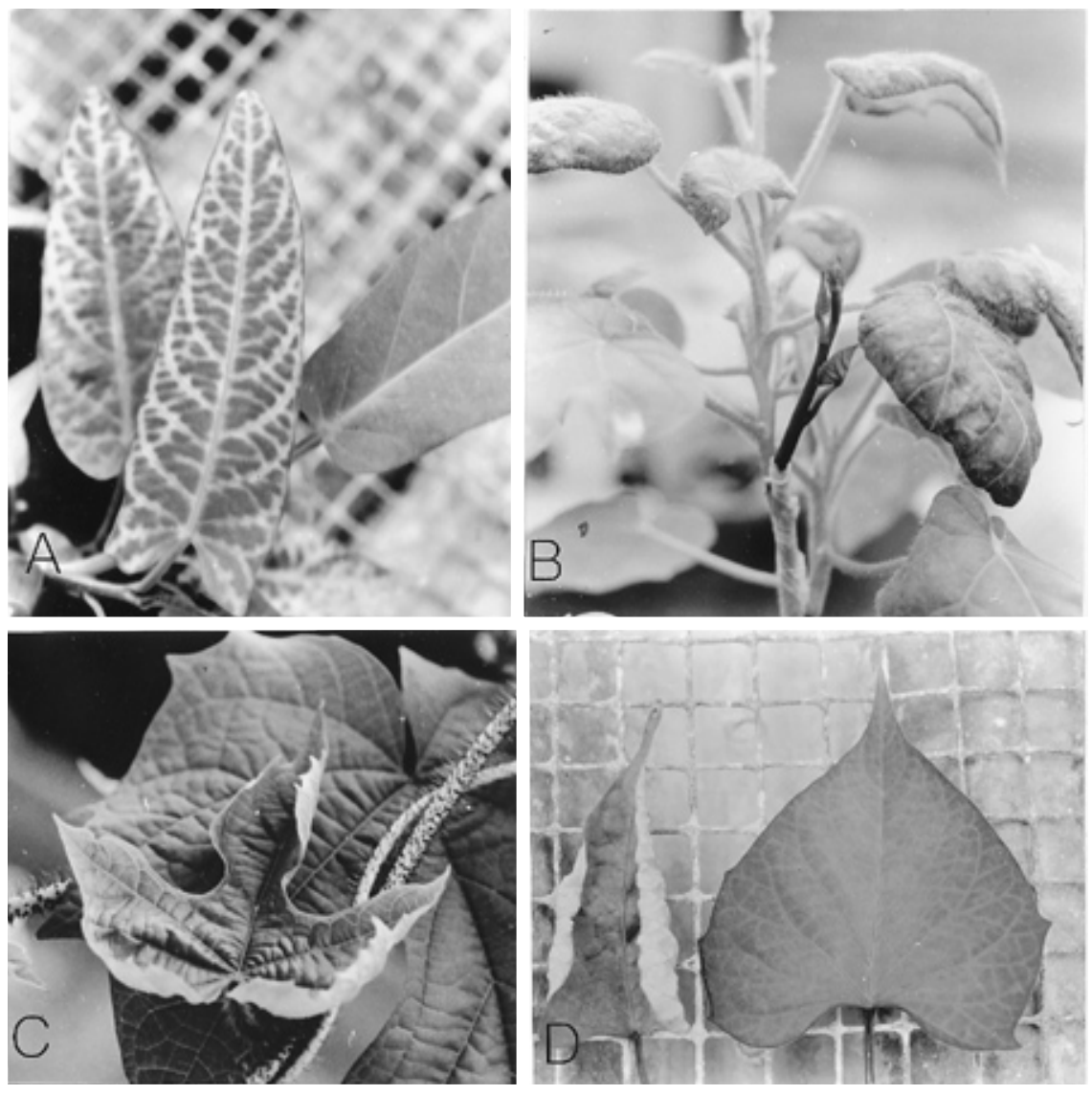

Fig. 1. Symptoms induced by the United States isolate of sweet potato leaf curl virus after graft inoculation to (A) Ipomoea aquatica, (B) I. nil, (C) I. setosa, and (D) I. batatas cv. W-285 (infected and healthy).
Polymerase chain reaction (PCR). PCR experiments were conducted using total DNA extracted by the method of Dellaporta et al. (4) from 0.5 to $1 \mathrm{~g}$ of $I$. aquatica, I. nil, I. setosa, I. cordatotriloba, and $I$. batatas infected with SPLCV-US or noninfected. DNA was suspended in $500 \mu \mathrm{l}$ of sterile $\mathrm{ddH}_{2} \mathrm{O}$, and $1 \mu \mathrm{l}$ was used for PCR reactions. Similar extracts were conducted using 30 to 50 viruliferous whiteflies with DNeasy. Total DNA was extracted from 15 to 20 viruliferous whiteflies using the protocol of Zeidan and Czosnek (20). In some experiments, DNA ( 2 to $3 \mathrm{~kb}$ and 1 to $1.2 \mathrm{~kb}$ ) obtained by Dellaporta's method was further purified after electrophoresis using UltraClean 15 DNA purification kit (MO BIO Laboratories Inc., Solana Beach, CA). DNA extractions using DNeasy were performed also. Two sets of degenerate primers, one reported to amplify subgroup III geminiviruses (AV494/AC1048) (19) and another reported to amplify four distinct geminiviruses (PAL1v1978/PAR1c496) (16), were used in all PCR experiments. oligonucleotide primers were synthesized by the Gene Lab (Louisiana State University). The final PCR reaction mixtures $(50-\mu$ l total volume) contained $2.5 \mathrm{mM} \mathrm{MgCl} 2,1 \times \mathrm{PCR}$ reaction buffer, $200 \mu \mathrm{M}$ dNTP mixture, 0.2 $\mu \mathrm{M}$ of each primer, 2.5 units of Taq DNA Polymerase (Promega, Madison, WI), and $1 \mu \mathrm{l}$ of DNA sample. DNA from plants infected with PHV and BGMV-FL were used as positive controls. DNA from healthy plants was also included in these experiments. PCR was performed in a DNA thermal cycler (Perkin-Elmer Cetus, Norwalk, CT) with 35 cycles (50 cycles in some experiments), each consisting of 1 $\min$ at $94^{\circ} \mathrm{C}, 1 \mathrm{~min}$ at $45^{\circ} \mathrm{C}$, and $3 \mathrm{~min}$ at $72^{\circ} \mathrm{C}$. A final extension step of $10 \mathrm{~min}$ at $72^{\circ} \mathrm{C}$ also was included. PCR products were separated by electrophoresis and stained with ethidium bromide. Selected gels were used for Southern blots as described above.

Electron microscopy. Tissue samples (veins, with adjacent mesophyll) from SPLCV-US infected and healthy $I . a q$ uatica, I. nil, I. setosa, and I. cordatotriloba were fixed for electron microscopy studies. Samples were fixed with $4 \%$ glutaraldehyde in $0.05 \mathrm{M}$ cacodylate buffer ( $\mathrm{pH}$ not adjusted) for $2 \mathrm{~h}$ at room temperature, followed by three washings with buffer (20 min each). After postfixation in $1 \%$ osmium tetroxide for $2 \mathrm{~h}$, samples were washed briefly with $\mathrm{ddH}_{2} \mathrm{O}$ and stained with $0.5 \%$ uranyl acetate at $4^{\circ} \mathrm{C}$. Infiltration was achieved with $50 \%$ (vol/vol) London Resin White in $100 \%$ ethanol. Blocks were polymerized at $60^{\circ} \mathrm{C}$ for $8 \mathrm{~h}$. Ultrathin sections were stained in lead citrate and observed using a Jeol transmission electron microscope. Symptomatic leaves of I. aquatica and I. cordatotriloba, I. nil, and whiteflies that had fed on infected plants for more than 1 week 
were homogenized in $0.1 \mathrm{M}$ sodium phosphate buffer, pH 7.0 (1:2, wt/vol). After staining with $2 \%$ uranyl acetate, samples were examined with the electron microscope.

\section{RESULTS}

Host reaction. Symptoms incited by SPLCV-US on I. aquatica, I. cordatotriloba, and I. fistulosa consisted of yellow vein mottle and mild leaf curling (Fig. 1A). I. alba, I. lacunosa, I. lobata, I. nil, I. tiliaceae, and I. trifida reacted with severe leaf curling, interveinal chlorosis, and stunting (Fig. 1B). I. setosa reacted with varying degrees of mild leaf curling, interveinal chlorosis, and stunting (Fig. 1C). I. pupurea and I. batatas cvs. Beauregard, TIB-8, Tanzania, and No. 29 did not show symptoms, although the virus could be recovered in back-inoculations to I. nil. W285 showed transient leaf curling (Fig. 1D). Coinfections of SPFMV and SPLCV-

Table 1. Sweet potato whitefly (Bemisia tabaci biotype B) transmission of the United States isolate of sweet potato leaf curl virus after 2-day acquisition and transmission feeding periods ${ }^{\mathrm{a}}$

\begin{tabular}{|c|c|}
\hline Whiteflies per plant & $\begin{array}{l}\text { Infected plants/ } \\
\text { plants tested }^{\mathrm{b}}\end{array}$ \\
\hline 1 & $2 / 75$ \\
\hline 5 & $1 / 25$ \\
\hline 10 & $2 / 18$ \\
\hline 20 & $4 / 17$ \\
\hline 30 & $7 / 15$ \\
\hline 40 & $7 / 13$ \\
\hline
\end{tabular}

a Acquisition hosts were Ipomoea aquatica and I. setosa and transmission host was I. nil.

${ }^{\mathrm{b}}$ Individual I. nil plants were exposed once (for

2 days) to the given number of viruliferous whiteflies.
US in I. setosa and I. nil resulted in severe leaf distortion, general chlorosis, and stunting. Mechanical inoculations were unsuccessful, as determined by lack of symptoms and negative results of Southern hybridizations.

Whitefly transmissions. Transmission rates using various numbers of the sweet potato whitefly are shown in Table 1. Normally, symptoms developed within 10 to 16 days after transmission. Attempts to transmit SPLCV-US using T. abutilonea failed. Symptoms were not obtained nor virus detected from transmission experiments to $N$. glauca, $C$. annuum, D. stramonium, L. esculentum, or $N$. clevelandii.

Molecular hybridization. DNA probes prepared with component A of BGMV-GA, TMoV-FL, PHV, and TYLCV-DR hybridized with a 2.6-kb DNA band present in total DNA extracts from plants infected with SPLCV-US (Fig. 2). Additionally, a DNA band of approximately $1.1 \mathrm{~kb}$ was consistently obtained in total DNA extracts and hybridized with all four probes. Probes prepared with the $\mathrm{B}$ component of these geminiviruses did not hybridize with DNA extracts from infected plants. Observed relative nucleic acid yields were slightly greater when extracted from I. cordatotriloba or I. aquatica but very low when I. batatas was the source host (Fig. 2B). DNA extractions using DNeasy did not improve SPLCV-US associated DNA yields.

PCR. Whether using DNeasy, Dellaporta's DNA purification method, or gelpurified DNA, we were unable to amplify SPLCV-US DNA products in quantities that could be visualized by ethidium bromide staining. However, Southern blots from amplifications with primers AV494/ AC1048 revealed PCR products of approximately $600 \mathrm{bp}$ and $550 \mathrm{bp}$ when the TYLCV-DR probe was used. These results were consistently obtained from I. cordatotriloba and less consistently from $I . a q-$ uatica or I. setosa. PCR products were not obtained from viruliferous whiteflies or from I. batatas. Primers PAL1v1978/ PAR1c496 did not amplify any SPLCV-US specific DNA, but fragments of expected size were obtained when BGMV-FL or PHV DNA was used.

Electron microscopy. Fibrillar inclusions and granular aggregates of viruslike particles were observed in the nucleus of infected I. cordatotriloba (Fig. 3). Similar inclusions were not observed in healthy tissues. These inclusions were not frequently detected. We did not detect these inclusions in the three other Ipomoea species examined. Geminivirus particles were not observed after negative staining the homogenates of infected plants or whiteflies.

\section{DISCUSSION}

During the early 1960s, several whitefly-transmitted viruslike diseases were reported to occur in sweet potato in the United States $(5,7,8)$. However, the putative viruses were not isolated or characterized, and no further research was published to confirm these reports. Because of the lack of defined symptoms induced by whitefly-transmitted viruses on currently used commercial sweet potato cultivars, it is likely that these viruses have been overlooked. SPLCV-US did not induce leaf curl or any other symptoms on Beauregard, TIB-8, Tanzania, or No. 29. It

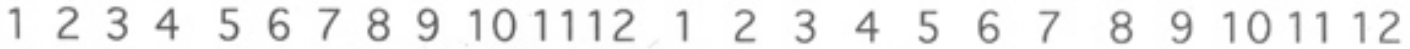

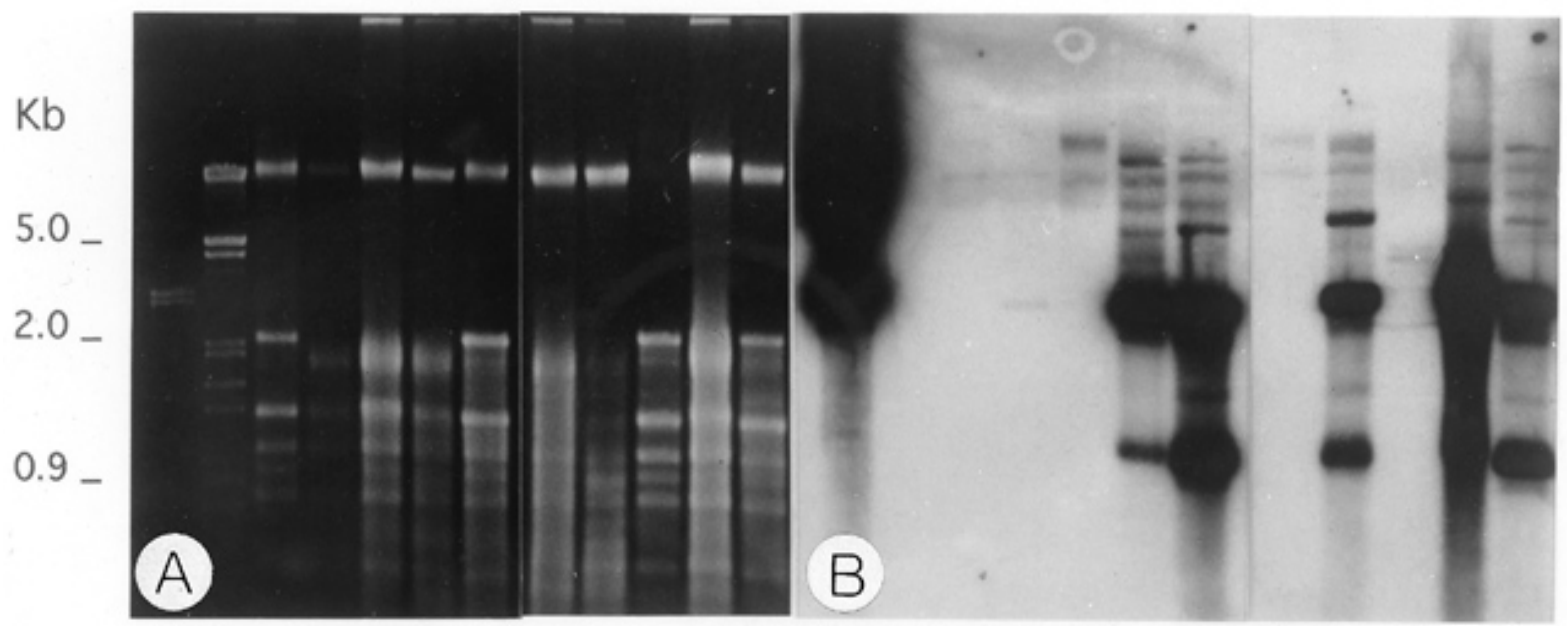

Fig. 2. Detection of the United States isolate of sweet potato leaf curl virus from various Ipomoea species using a probe prepared with DNA recombinant plasmid of an isolate of tomato yellow leaf curl geminivirus from the Dominican Republic (TYLCV-DR). (A) Agarose gel (1.2\%) containing DNA from: lane 1, TYLCV-DR component A; lane 2, DNA ladder (Lambda DNA cut with HindIII/EcoRI); lane 3, healthy I. batatas; lane 4, infected I. batatas cv. Beauregard; lane 5, healthy I. setosa; lane 6, infected I. setosa; lane 7, infected I. cordatotriloba; lane 8, healthy I. nil; lane 9, infected I. nil; lane 10, healthy I. aquatica; lane 11, infected I. aquatica; and lane 12, infected I. cordatotriloba. Total DNA was extracted from 1.0 g of tissue and the equivalent to $0.025 \mathrm{~g}$ loaded in the gel. DNA samples in lanes 7 and 12 are from two independent extractions. (B) Southern blot DNA hybridization of the gel. Probe was prepared by direct labeling using the ECL kit (Amersham). Exposures to X-ray film were for $2 \mathrm{~h}$. 
is fortuitous that W-285 developed unique leaf curl symptoms when infected with SPLCV-US. Similarly, we have noted lack of symptom induction by a whitefly-transmitted closterovirus infecting sweet potato (R. A. Valverde and C. A. Clark, unpublished). The fact that unreported viruses have been found in symptomless sweet potato illustrates the need for a systematic survey of sweet potatoes in the United States for viruses.

Leaf curling symptoms on I. batatas breeding line W-285 were not observed throughout the year under greenhouse conditions. Molecular hybridization tests revealed that SPLCV-US titer in I. batatas appears to be very low. Nevertheless, the virus was readily detected by graft-inoculations to indicator hosts, especially $I$. $a q$ uatica and $I$. nil. This suggests that specific detection of this virus from sweet potato may require grafting to an indicator followed by molecular hybridization or PCR from the indicator host tissue.

Relatively low amounts of geminivirusspecific PCR products were obtained from
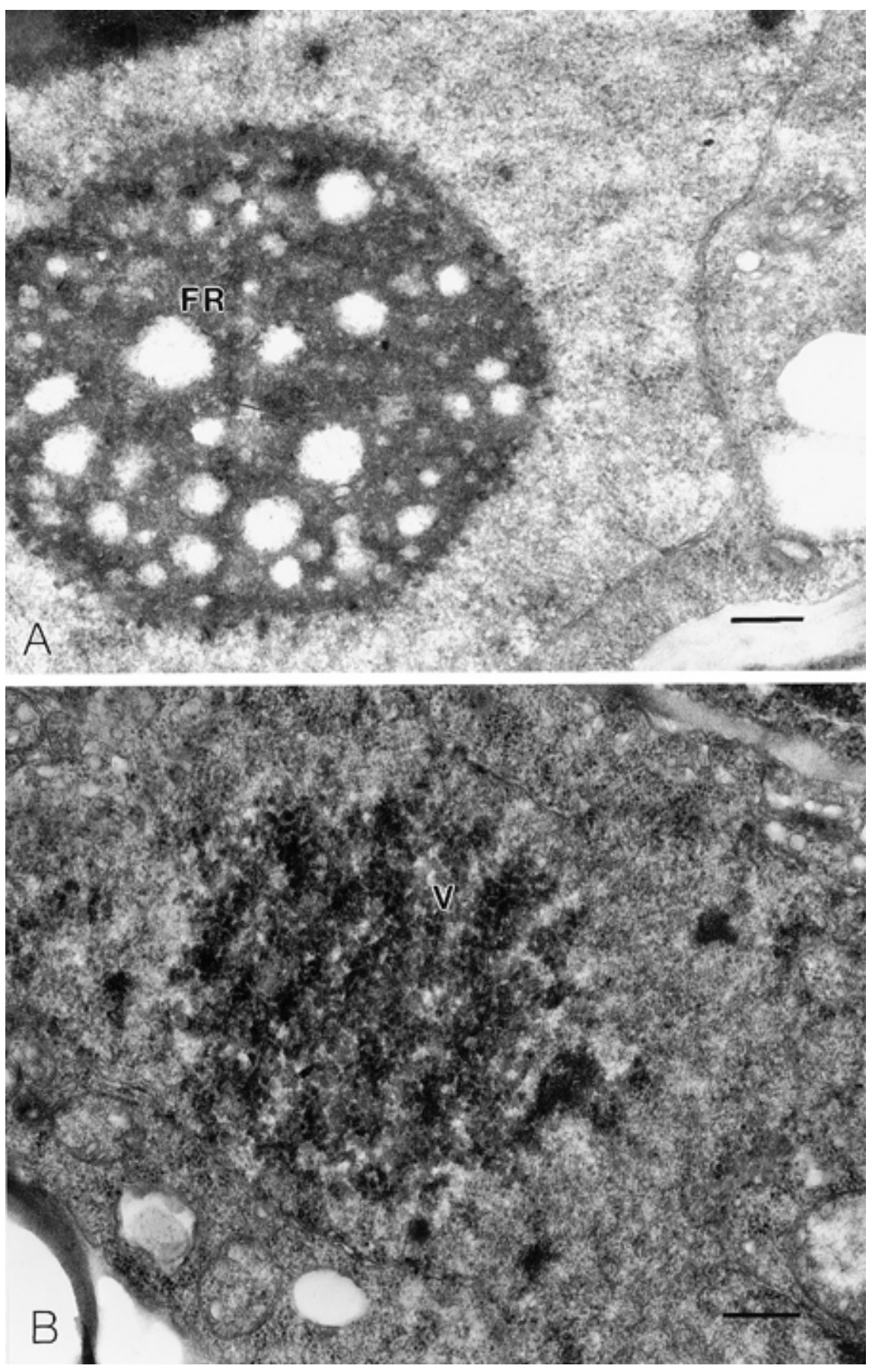

Fig. 3. Ultrathin sections of leaves from Ipomoea cordatotriloba infected with the United States isolate of sweet potato leaf curl virus: (A) nucleus of a phloem parenchyma cell showing fibrillar inclusions (FR) and (B) aggregates of viruslike particles (V). Scale bars $=300 \mathrm{~nm}(\mathrm{~A})$ and $400 \mathrm{~nm}$ (B). three different hosts infected with SPLCVUS, although DNA amounts were not detectable with ethidium bromide staining. However, Southern blot hybridizations using TYLCV-DR probes revealed the presence of these PCR products. Dilutions or increases in concentrations did not improve yields of PCR products, but increasing the number of PCR cycles (from 35 to 50) slightly improved the DNA yields from SPLCV-US infected plants (data not shown). We were unable to reamplify these PCR products. We are not sure why we were unable to obtain relatively high amounts of PCR products, but some factors that could be involved are low homology between primers and target DNA, low concentration of target DNA, plant inhibitors, and low target dsDNA concentration.

Results obtained with SPLCV-US, such as symptomatology, transmission by $B$. tabaci biotype $\mathrm{B}$, positive hybridization with clones to four geminiviruses, PCR amplification with geminivirus-specific primers, and cytopathology, support placing this virus in the geminivirus group. SPLCV-US geminivirus reported here has similar properties to SPLCV reported from Taiwan and Japan $(1,14)$. In contrast, ICLCV from Israel (3) appears different; it did not infect I. pupurea or I. trichocarpa and did not induce consistent or reliable symptoms on I. nil. Yet the latter two reacted with severe and consistent symptoms when inoculated with SPLCV-US. Furthermore, unlike ICLCV, virus particles were not detected from infected tissues of I. nil. Simultaneous comparisons of biological properties and DNA sequences of these three putative geminiviruses are needed to determine their relatedness.

In molecular hybridization studies, probes generated using full-length clones of TYLCV-DR gave a stronger signal in Southern blots with SPLCV-US DNA than that obtained with BGMV-GA, TMoV-FL, or PHV (component A). Based on the relative strength of the hybridizations, this virus appears to be more closely related to TYLCV-DR than the other viruses tested. Moreover, lack of hybridization with component B of TMoV-FL, BGMV-GA, and PHV suggests that it could be a monopartite geminivirus or have a unique component $\mathrm{B}$ sequence. The 2.6-kb DNA band associated with SPLCV-US was not affected by digestions with EcoRI, HindIII, BamHI, PstI, NcoI, or ClaI, but it was degraded by DNase $\mathrm{I}$ and $\mathrm{S}_{1}$ nuclease, suggesting that it may consist of ssDNA.

The fact that a geminivirus that induces leaf curl symptoms in sweet potato has now been found in three widely separated regions (United States, the Middle East, and Southeast Asia) suggests that this virus(es) may be more widely distributed than realized. A report from Africa (17) describes similar symptoms being induced in I. aquatica, but SPLCV has not been reported in Africa. The present distribution 
of SPLCV-US in the United States is not known. However, it was also detected in another breeding line (W-239) which was planted in various sweet potato growing regions of the United States in 1994 and 1995.

Currently, molecular characterization, development of reliable detection protocols, and effects on sweet potato yield and quality are under investigation.

\section{ACKNOWLEDGMENTS}

We thank R. L. Gilbertson (University of California, Davis) and R. Rivera-Bustamante (CINVESTAV, Mexico) for providing geminivirus clones; J. Polston (University of Florida) for providing BGMV; H. Hsu (National Chung Hsing University, Taiwan) for providing unpublished data on SPLCV; K. S. Kim (University of Arkansas) for advice on cytopathology; S. Winter (DSM, Braunschweigh, Germany) for technical advice; and M. Hoy, D. Dufresne, and E. Souto for technical assistance.

\section{LITERATURE CITED}

1. Chung, M.-L., Liao, C.-H., Chen, M.-J., and Chiu, R.-J. 1985. The isolation, transmission and host range of sweet potato leaf curl agent in Taiwan. Plant Prot. Bull. (Taiwan) 27:333341.

2. Clark, C. A., and Moyer, J. W. 1988. Compendium of Sweet Potato Diseases. The American Phytopathological Society, St. Paul, $\mathrm{MN}$

3. Cohen, J., Milgram, M., Antignus, Y., Pearlsman, M., Lachman, O., and Loebenstein, G. 1997. Ipomoea crinkle leaf curl caused by a whitefly-transmitted gemini-like virus. Ann. Appl. Biol. 131:273-282.

4. Dellaporta, S. L., Wood, J., and Hicks, J. B. 1983. A plant DNA minipreparation: Version II. Plant Mol. Biol. Rep. 121:257-268.

5. Girardeau, J. H., and Ratcliffe, T. J. 1960. The vector-virus relationship of the sweetpotato whitefly and a mosaic of sweetpotatoes in South Georgia. Plant Dis. Rep. 44:48-50.

6. Green, S. K., Luo, C. Y., and Wu, S. F. 1992. Elimination of leafcurl virus of sweet potato by meristem tip culture, heat and ribivirin. Plant Prot. Bull. (Taiwan) 34:1-7.

7. Hildebrand, E. M. 1959. A whitefly, Trileurodes abutilonea, an insect vector of sweetpotato feathery mottle in Maryland. Plant Dis. Rep. 43:712-714.

8. Hildebrand, E. M. 1961. Relations between whitefly and sweetpotato tissue in transmission of yellow dwarf virus. Science 133:282283.

9. Liang, Y. G., Yang, T. C., and Ko, N. J. 1990. Occurrence and diagnosis of geminiviruses in Taiwan. Plant Prot. Bull. (Taiwan) 32:136144.

10. Maniatis, T., Fritsch, E. F., and Sambrook, J. 1982. Molecular Cloning: A Laboratory Manual. 2nd ed. Cold Spring Harbor Laboratory, Cold Spring Harbor, NY.

11. Moyer, J. W., Jackson, G. V. H., and Frison, E. A., eds. 1989. FAO/IBPGR Technical Guidelines for the Safe Movement of Sweet Potato Germplasm. Food and Agriculture Organization of the United Nations, Rome/International Board for Plant Genetic Resources, Rome.

12. Moyer, J. W., and Larsen, R. C. 1991. 18. Management of insect vectors of viruses infecting sweet potato. Pages 341-358 in: Sweet
Potato Pest Management, A Global Perspective. R. K. Jansson and K. V. Raman, eds. Westview Press, Boulder, CO.

13. Moyer, J. W., and Salazar, L. F. 1989. Viruses and viruslike diseases of sweet potato. Plant Dis. 73:451-455.

14. Osaki, T., and Inouye, T. 1991. Transmission characteristics and cytopathology of a whitefly-transmitted virus isolated from the sweet potato leaf curl disease. Bull. Univ. Osaka Prefecture, Ser. B, Agric. Biol. 43:1119.

15. Pio-Ribeiro, G., Winter, S., Jarret, R. L., Demski, J. W., and Hamilton, R. I. 1996. Detection of sweet potato virus disease associated closterovirus in a sweet potato accession in the United States. Plant. Dis. 80:551-554.

16. Rojas, M. R., Gilbertson, R. L., Russell, D. R., and Maxwell, D. P. 1993. Use of degenerate primers in the polymerase chain reaction to detect whitefly-transmitted geminiviruses. Plant Dis. 77:340-347.

17. Rossel, W. H. 1981. Sweet potato virus disease (SPVD). Pages 74-75 in: Annu. Rep. IITA, 1980.

18. Valverde, R. A., Arancibia, R. A., and Can, F. 1994. Nonradioactive probes by direct labeling of ssRNA from dsRNA. BioTechniques 17:70-72.

19. Wyatt, S. D., and Brown, J. K. 1996. Detection of subgroup III geminivirus isolates in leaf extracts by degenerate primers and polymerase chain reaction. Phytopathology 86:1288-1293.

20. Zeidan, M., and Czosnek, H. 1991. Acquisition of tomato yellow leaf curl virus by the whitefly Bemisia tabaci. J. Gen. Virol. 72:2607-2614. 